\title{
Cognitive Job Demands, Presenteeism and Procrastination: The Moderating Role of
}

\section{Psychological Capital}

\author{
* Dr. Nosheen Sarwat (Corresponding Author) \\ ** Dr. Raza Ali \\ *** Dr. Tariq Iqbal Khan
}

\begin{abstract}
Using the job-demands resource theory, the basic purpose of this article was to study the relationship between cognitive job demands, stress-related presenteeism, and procrastination. Stress-related Presenteeism is a kind of psychological state in which individuals are present at work but due to stress are not able to expend their full energies at work and remain distracted. We also tested for the combined effect of psychological capital and cognitive job demands on stress-related presenteeism. Data were collected from 192 full-time working professionals and analyzed using step-wise regression and bootstrapping. Results revealed that individuals with strenuous job demands were facing stress-related presenteeism and were involved in procrastination. Findings also supported the moderating role of psychological capital as an effective personal resource in reducing stress-related presenteeism. In the end implications for practice have been discussed.
\end{abstract}

Keywords: Cognitive Job Demands, Stress-Related Presenteeism, Procrastination, Psychological Capital

\section{Introduction}

The goal of behavioral scientists for over 100 years has been to investigate the fact that why people behave in a certain way at work. Answers to such questions would be incomplete without the discussion of the individual characteristics, the task characteristics, and the social context in which the task is taking place (Barrick, Mount \& Li, 2013). Today's work environment is dynamic and the challenges faced by individuals in contemporary organizations are countless; be it changing information technology, fierce competition at both local, national and global level, the shift in the paradigm of business from being product-oriented to service-oriented, demographic changes, the changing nature of internal organizational structures and even the traditional understanding of job as a set of fixed tasks (Cascio, 1995). Achieving long-term success would require individuals who are healthy and who can work without being stressed out and distracted, and who can devote all their energies to accomplish work-related tasks. Unhealthy employees add to the cost burden of organizations in terms of medical claims and missed work in the form of absenteeism.

Here an important question is that do all employees who get ill choose to be absent from work. We all have met colleagues coughing and sneezing and trying to get their jobs done, even at times we have experienced the same phenomenon but still managed to show up for work. Organization scholars term this behavior as presenteeism or sickness-related presenteeism and define it as 'attending work while ill' (Johns, 2011). However, researchers studying presenteeism also argue that there are multiple competing understandings of presenteeism, while some belief it to be a negative behavior others have developed positive understandings of presenteeism (Ruhle et al., 2019).

A rather naïve addition to the presenteeism literature is stress-related presenteeism. It is defined as a kind of behavior that is passive and refractive. Employees indulged in this type of behavior are present at their work but distracted since their cognitive energies are diverted somewhere else and they are not able to concentrate on work-related tasks (Gilbreath \& Karimi 2012). It can be defined more specifically as a situation in which employees are physically present in their workplace, but their mental resources are not concentrated and distracted by the job. Due to this distraction which

\footnotetext{
* Institute of Management Sciences, Bosan Road, Bahauddin Zakariya University Multan Email: nosheensarwat@bzu.edu.pk

** Institute of Management Sciences, Bosan Road, Bahauddin Zakariya University Multan

Email: razaali@bzu.edu.pk

*** Department of Management Sciences, University of Haripur Email: Tariqiqbalkhan@uoh.edu.pk
} 
is more due to stress they may not be able to devote full attention towards their work and involve in delaying tactics at work. Whether such presenteeism is induced by cognitive job demands, and whether employees suffering from such presenteeism procrastinate, are two key research questions that this study attempts to address. Moreover, according to the job demands resource theory, when individuals possess certain personal resources like psychological capital then the harmful effects of stressful job demands can be mitigated. Therefore, 'does psychological capital weaken the effect of cognitive job demands on stress-related presenteeism?' is another research question that attracts our attention.

\section{Research Objectives}

Using the job-demands resource theory, the basic purpose of this article is to study the role of cognitive job demands as an antecedent of stress-related presenteeism, and the role of procrastination as an outcome of stress-related presenteeism. To fulfill this purpose, this study addresses the following research objectives:

RO1: To examine the effect of cognitive job demands on stress-related presenteeism.

RO2: To test the impact of stress-related presenteeism on procrastination.

RO3: To investigate the effect of cognitive job demands on procrastination.

RO4: To test the mediating effect of stress-related presenteeism in the relationship between cognitive job demands and procrastination.

RO5: To study the moderating effect of psychological capital on the relationship between cognitive job demands and stress-related presenteeism.

\section{Literature Review}

\section{Cognitive job demands and Procrastination:}

Job demands are aspects of work that require sustained effort on the part of workers and are associated with some costs (Tim, Bakker \& Derks, 2013). In his dynamic model on presenteeism Johns (2010) argued that certain aspects of job demands may lead to presenteeism. Such demands may require the individual to invest extra energy in extraneous tasks providing no growth potential and may also deplete the individual's stock of resources (LePine et al., 2005; Tims et al., 2013; Van den Broeck et al., 2010). Examples of hindering job demands are conflict, emotional demands, cognitive demands and job insecurity etc. In a meta-analysis, Crawford et al., (2010) analyzed 64 different samples and confirmed that hindering job demands like cognitive job demands were negatively related to engagement.

Many of the workplace tasks that individuals engage in are being performed unwillingly due to all sorts of reasons and individuals tend to delay these tasks as much as possible. Tuckman \& Sexton (1989) call this behavior the lack of 'self-regulated performance' and term it as procrastination. When job demands are perceived as a hindrance they can generate negative emotions like cognitive job demands can have negative impacts on employee's motivation to work and as a result, they may decrease their work efforts or even indulge in withdrawal behavior (Schaufeli \& Taris, 2005). This delaying behavior has been further expanded in a study on the correlates of workplace procrastination. In a study on daily job crafting, Petrou et al., (2012) argued that when individuals face demands for they which they don't have the corresponding resources like cognitive job demands they reduce their work efforts and tend to delay tasks. In another study, using the JD-R model as a basis, the authors explained that when individuals are confronted with high job demands at work, which they perceive as threats to their personal growth it results in high strain and low motivation, as a result of which they feel boredom from their current work activities which may result in procrastinating behavior (Metin, Taris \& Peeters, 2016). Based on this discussion it is hypothesized that

Hypothesis 1 There is a positive relationship between cognitive job demands and procrastination.

\section{Cognitive Job-Demands and Stress-Related Presenteeism}

The JD-R model has been used by several researchers to study the effects of various job demands on a variety of outcomes. The job demands that typically form a part of the JD-R research are time pressure, role conflict, work overload, role ambiguity, physical demands, and emotional demands (see Crawford et al., 2010; Fernet, Austin, Trépanier, \& Dussault, 2013). When employees feel stress towards the fulfillment of certain demands, they appraise them to be more of a hindrance than a challenge. These are hindering demands that hinder an individual's goal achievement (Dormann \& Zapf, 2004). Examples of hindrance demands typically used in research studies include: role conflict, role ambiguity cognitive demands, and emotional demands (Crawford et al., 2010). 
The evidence stated above depicts emotion and cognitive job demands as a hindrance towards goal achievement at work and based on the assumptions of the JD-R model (Demerouti \& Bakker, 2011) such job demands initiate an energy-depleting process which may result in the employee facing stressful conditions at work. Ample empirical evidence is present on the positive relations between such type of job demands and presenteeism (see for example Coutu et al., 2015; McGregor et al., 2016; Sarwat \& Shahzad, 2017). Further, based on the postulates of the COR theory (Hobfoll, 2001), it is hypothesized that when though these demands will be depleting the resources of the employee but even under such stressful condition, the individual will choose to be present at work in spite being distracted so that available resources can be used to cope up for the lost work. In a meta-analytic test conducted by Crawford, LePine, and Rich (2010) employees who appraised job demands as hindrances their demands related negatively to their ability to work with full devotion and in contrast, employees who appraised demands as challenges were found to be more engaged at work. According to Hobfoll (2001), when individuals are not able to handle hindering job demands they start losing resources, this loss may require them to put in extra efforts, to gain the resources lost, and hence they will attend work, even if they are not able to focus.

Hypothesis 2 There is a positive relationship between cognitive job demands and stress-related presenteeism

\section{Stress-Presenteeism and Procrastination}

Procrastination is dragging a process that is under the control of the individual, where delay itself is under the control of the individual and the task is the one to be done. (Ackerman \& Gross, 2005). Though it may be a formal requirement of the job but many of the workplace tasks that individuals engage in are being performed unwillingly due to all sorts of reasons and individuals tend to delay these tasks as much as possible, no doubt they have control over it. Tuckman \& Sexton (1989) call this behavior the lack of 'self-regulated performance' and term it as procrastination.

Though the construct of academic procrastination has been of most interest to education researchers, it has been till recently that organizational behavior theorists have been particularly interested in studying procrastination at the workplace. With statistics pointing to the financial consequences organizations can face due to procrastinators (Malachowski, 2005); and also increased burden of the lost work of procrastinators on employees who do not delay results in serious issues to be addressed by organizations (Pychyl \& Flett, 2012). A comprehensive review of literature by Steel has provided some insights into the tasks that people chose to delay and to the individual differences that exist between procrastinators and non-procrastinators. Tasks with low value and low expectancy and individuals with low self-efficacy and low conscientiousness were believed to procrastinate more (Steel, 2007). Some researchers also argue that task characteristics and individual differences can also interact and account for procrastination at the workplace (Skorownski \& Mirowska, 2013).

A sparse amount of research has been reported on presenteeism and procrastination. In these studies, non-work-related presenteeism has been used as the main construct. The results reported by these studies have identified procrastination as a significant predictor (Wan et al., 2014) and outcome of procrastination (Akhtar \& Malik, 2016). There is a reason to believe from the results of these studies that individuals involve in procrastination that is why they perform personal activities at work or because they are involved in personal activities at work they chose to delay the task at hand. However, in stress-related presenteeism people are under stress, they choose to be present but since they are not being able to invest their full cognitive energies (Gilbreath \& Karimi, 2012), they may be less responsive to job demands since their motivation is low. To deal with stress, individuals indulge in coping mechanisms, and delaying work at this time would seem to be a more appropriate behavior with positive outcomes for the procrastinator (Chu and Choi, 2005).

Hypothesis 3 There is a positive relation between stress-related presenteeism and procrastination Mediating Role of Stress-Related Presenteeism between Cognitive Job Demands and Procrastination

Procrastination is defined as the intended delay of a task that is under the control of the individual and when that task has to be completed (Ackerman \& Gross, 2005). The individual is well aware that the task must be accomplished but may not be able to find the motivation to complete the task. Researchers have identified several reasons due to which individuals procrastinate. For example, they may be stressed out or bored at work (D'Abate, 2005). People also tend to delay working on those tasks which they do not find motivating, difficult to perform, unpleasant, or which they are forced to 
do (Blunt \& Pychyl, 2005). Sometimes individuals also procrastinate to relieve stress (Ackerman \& Gross, 2005), since temporarily detaching oneself from the task at hand which may be causing stress is a kind of a coping technique to avoid stress.

Researchers have characterized procrastinators as being less engaged at work (Metin, Taris \& Peeters, 2016) since they do not tend to have the vigor and dedication to accomplish the task, which are identifying characteristics of work engagement (Bakker, Schaufeli, Leiter, \& Taris, 2008). When people are not fully devoting their cognitive energies at work i.e., stress-related presenteeism (Gilbreath \& Karimi 2012) and though are present at work but less engaged then they indulge more in delaying the task at hand to relieve the stress. Procrastination and presenteeism were also found to be directly related in a study conducted by Wan et al., (2014).

Based on previous studies which have utilized the JD-R model (Bakker \& Demerouti, 2007) to explain the effects of job demands on procrastination (Metin, Taris \& Peeters, 2016), the present study also used the health impairment hypothesis of the JD-R model to explain the effects of differentiating job demands on procrastination. This hypothesis explains that when individuals have high job demands or job demands that present the individual with unchallenging tasks and low resources, they would experience feelings of detachment, low engagement at work (Bakker \& Demerouti, 2007) in the case of the present study that would be stress-related presenteeism, which can result in procrastination. In a study conducted on the correlates of presenteeism at work, the authors argued that when employees are not able to find the right emotion and cognitive stimulation to perform a task at work they tend to be less engaged (Metin, Taris \& Peeters, 2016).

Hypothesis 4 Stress-related presenteeism will mediate the relation between cognitive job demands and procrastination.

Moderating Role of Psychological Capital for the relationship between Cognitive Job Demands and Stress-Related Presenteeism

Individuals must be able to utilize the personal resources they bring to the workplace to the best of the organization's advantage (Newman, Ucbasaran, Zhu \& Hirst, 2014). The job demands resource theory also emphasizes the importance of personal resources like psychological capital in coping with job demands. The construct of psychological capital is based on four main psychological resources i.e. self-efficacy, optimism, hope, and resilience, which help to measure a person's psychological capacities which should be further developed so that his performance can be improved (Luthans \& Youssef, 2004; Luthans \& Youssef, 2007; Luthans, Youssef \& Avolio, 2007). Personal resources are individual-level characteristics and show associations with one's ability to sustain in difficult times and also positively influence the work environment (Schaufeli \& Taris, 2014). Researchers have argued for the importance of personal resources along with job resources so that employees can successfully adapt to their work environments (Xanthopoulou et al., 2007). Personal resources are considered to work similarly to job resources by performing the following functions; (i) they help individuals cope with demanding situations and associated costs, (ii) they help individuals in achieving their goals, and (iii) they foster individual growth and progression (Xanthopoulou, Bakker, Demerouti \& Schaufeli, 2009).

When individuals appraise their job demands as hindering in goal achievement then personal resources play a crucial role in keeping the individual engaged at work (Xanthopoulou et al., 2007; Xanthopoulou et al., 2009). At the individual level, the combined effect of PsyCap has been studied with several different variables to assess its impact on various outcomes (Abbas et al., 2014; Newman et al.,2014).In the presenteeism literature emphasis has been given to various personal resources like optimism and conscientiousness (see for example Miraglia \& Johns, 2016). In another study, researchers have studied the combined effects of emotional demands with personal resources like optimism and self-efficacy on work engagement based on the hypotheses presented in the JD-R model (Bakker, 2011), however they could only find support for the positive effect of self-efficacy on engagement and not optimism (Xanthopoulou, Bakker \& Fischbach, 2013). Such empirical evidence warrants further exploration of the interactive effects of various other personal resources (like psycap in this study) and hindering demands like cognitive job demands and its effect on employees' engagement at work. Since engaged employees are expected to be fully devoted at work as compared to employees who are present at the job but not being able to fully devote their energies at work due to stress (i.e. stress-related presenteeism. Similarly, based on the assumptions of the JD-R theory 
(Bakker \& Demerouti, 2014), it is expected that the moderating relationship between hindering job demands and stress-related presenteeism will be weaker for people high in PsyCap and vice-versa.

Hypothesis 5 Psychological capital will moderate the relation between cognitive job demands and stress-related presenteeism, such that the relationship will be weaker for people with higher psychological capital.

\section{Methodology}

\section{Context of where the study is being conducted}

The present study is being conducted in the banking industry of Pakistan. With more than $90 \%$ of privatized banks, it is thought that by becoming more efficient and improving its internal systems, the banking industry of Pakistan can make a profound impact on the country's GDP. Currently, there are 44 banks, with 16,121 branches, and more than 15,000 ATMs (State Bank of Pakistan, 2020). Statistics have revealed that $86 \%$ of Pakistan's population is unbanked and still the industry is earning handsome profits and has the potential to do a lot more and compete globally (www.tribune.com). With the introduction of new banking reforms from 1974 to 1991 followed by privatization of banks, globalization pressure, neck throat competition, latest technology, and major restructuring and transformation, there have been a lot of changes in how banking is conducted in Pakistan today. These pressures have also resulted in changing working patterns and differentiated job demands from bank employees for which rigorous trainings have been offered to individuals working in banks. Researchers argue that due to these internal and external factors banking employees are undergoing substantial stress (Khattak, Khan, Haq, Arif \& Minhas, 2011). Keeping in view the attractiveness of the banking industry and stress levels faced by individuals working in this industry, we chose the banking industry in Pakistan for data collection. Moreover, many researchers have effectively tested western theories using samples from the banking industry of Pakistan as the respondents are welleducated and understand English (cf Abbas et al., 2014; Sarwat \& Abbas, 2020).

Research design Relational survey method was used to collect data. Since this is the most convenient and cost-effective way to collect data from a large population. The questionnaires were selfadministered.

Population and sample Full-time bankers working at various levels in banks including domestic and multinational banks in Pakistan formed the population of the current study. The study used convenience sampling and data were collected from three major cities, including Lahore, Rawalpindi, and Multan from the province of Punjab, which is densely populated and has a comparatively high rate of literacy with most of the banked population. The first author contacted various branches of the selected banks and questionnaires were distributed after consent from the respective branch managers of the selected branches of these banks. A total of 300 questionnaires were distributed, out of which 206 were received and 14 questionnaires were dropped due to incomplete data, thereby the final sample size comprised of 192 useable questionnaires bringing our response rate to $64 \%$.

Instruments The instruments used in the present study and their detail is given below. All measures were tapped on a five-point Likert scale except for mindfulness which was measured on a six-point Likert scale. Higher scores revealed higher-level constructs.

\begin{tabular}{|c|c|c|c|}
\hline Variable & $\begin{array}{l}\text { Instrument } \\
\text { Author(s) }\end{array}$ & No. of items & Sample items \\
\hline \multirow[t]{2}{*}{$\begin{array}{l}\text { Cognitive } \\
\text { demands }\end{array}$} & Cognitive demands & 7 & $\begin{array}{l}\text { Does your work require a great deal of } \\
\text { carelessness? }\end{array}$ \\
\hline & $\begin{array}{l}\text { (Van Veldhoven \& } \\
\text { Meijman, 1994) }\end{array}$ & & Do you have to work with a lot of precision? \\
\hline $\begin{array}{l}\text { Psychological } \\
\text { Capital }\end{array}$ & $\begin{array}{l}\text { Luthan, Avolio, } \\
\text { Avey, and Norman } \\
(2007) \text {. }\end{array}$ & 12 & $\begin{array}{l}\text { I can usually handle whatever comes my way. } \\
\text { I can get through difficult times at work } \\
\text { because I've experienced difficulty before. }\end{array}$ \\
\hline $\begin{array}{l}\text { Stress-related } \\
\text { presenteeism }\end{array}$ & $\begin{array}{l}\text { (Gilbreath and Frew, } \\
\text { 2008) }\end{array}$ & 6 & $\begin{array}{l}\text { I'm unable to concentrate on my job because of } \\
\text { work-related stress. } \\
\text { I delay starting new projects at work because of } \\
\text { stress. }\end{array}$ \\
\hline Procrastination & Tuckman (1991) & 5 & $\begin{array}{l}\text { I postpone starting on things I don't like to do. } \\
\text { I needlessly delay finishing jobs even when } \\
\text { they are important. }\end{array}$ \\
\hline
\end{tabular}

Control Variables: Due to their plausible effects on stress-related presenteeism, age, job nature, and experience were used as control variables. Next we conducted a one-way ANOVA comparing stress- 
related presenteeism across age, job nature and experience and results were significant for job nature $(\mathrm{F}=3.02, \mathrm{p}<.05)$ and experience $(\mathrm{F}=4.12, \mathrm{p}<.01)$.

Data Analysis and Results

Sample characteristics Respondents comprised of 56 females and 136 males with an average age of 33. Individuals with manager-level jobs comprised $68 \%$ of the sample; $80 \%$ of the sample respondents had a Master's degree, and more than $50 \%$ of the sample had an average work experience of more than 4 years.

Descriptive statistics

The basic descriptive statistics, bivariate correlations, and reliability estimates in parentheses (alpha coefficient) for all variables are shown in Table 1. The alpha reliabilities were all above 0.7 according to acceptable standards.

Table 1: Means standards deviations, alpha reliabilities, and correlations of study variables

\begin{tabular}{|c|c|c|c|c|c|c|c|c|c|c|}
\hline & Variables & Mean & SDV & 1 & 2 & 3 & 4 & 5 & 6 & 7 \\
\hline 1 & Age & 32.54 & 6.03 & & & & & & & \\
\hline 2 & Gender & 1.41 & 0.4 & $-.283^{* *}$ & & & & & & \\
\hline 3 & $\begin{array}{l}\text { Job Nature } \\
\text { Cognitive }\end{array}$ & 3.89 & 1.1 & $.159^{*}$ & -.059 & & & & & \\
\hline 4 & $\begin{array}{l}\text { Demands } \\
\text { Stress-related }\end{array}$ & 3.90 & 0.74 & .088 & $.13^{* *}$ & -.08 & (.86) & & & \\
\hline 5 & $\begin{array}{l}\text { Presenteeism } \\
\text { Psychological }\end{array}$ & 3.32 & 0.65 & -.11 & .02 & $.12^{*}$ & $.15^{* *}$ & $(.81)$ & & \\
\hline 6 & Capital & 4.11 & 0.94 & .092 & -.038 & -.123 & $.556^{* *}$ & $-.218^{* * *}$ & (.91) & \\
\hline 7 & Procrastination & 2.87 & 0.73 & -.029 & -.008 & .145 & $.190^{*}$ & $.35^{* *}$ & $-.352^{* *}$ & $(.81)$ \\
\hline
\end{tabular}

$\mathrm{N}=192, p<0.05^{* *}, p<0.01 *, \mathrm{SDV}=$ Standard Deviation, alpha reliabilities in parenthesis.

To test the main effects for hypotheses 1 and 2, we used multiple linear regression. We entered age, gender, and job nature in the first step followed by the independent variables in the second step. Table 2 (step 3) depicts the results for the main effects of psychological capital and cognitive demands on stress-related presenteeism. Psychological capital will moderate the relation between cognitive job demands and stress-related presenteeism $(\beta=.21, \mathrm{p}<.05)$ while cognitive demands were positively related to stress-related presenteeism $(\beta=.38, \mathrm{p}<.01)$. These results supported our hypotheses.

Bootstrap results for indirect effects of cognitive job demands on procrastination through stress-related presenteeism

Direct and Indirect Effects

The direct impact of cognitive demands on procrastination was insignificant $(\mathrm{B}=.00$, ns). Hypothesis 1 was thus rejected. Cognitive job demands had a positive effect on stress-related presenteeism (Hypothesis 2). The results in table 2 show the same $(\mathrm{B}=.15, \mathrm{p}<.05)$. The relationship between stress-related presenteeism and procrastination was positive and significant $(B=.28, p<.01)$ as shown in Table 2. We therefore accept Hypotheses 2 and 3. The bootstrap indirect effect of cognitive demands on procrastination was significant through stress-related presenteeism as the bootstrapped confidence interval did not include a zero, .04 CI [.06, .03]. The results supported our mediation hypothesis.

Table 2 Main effects and mediation of stress-related presenteeism in cognitive job demands and procrastination relationship

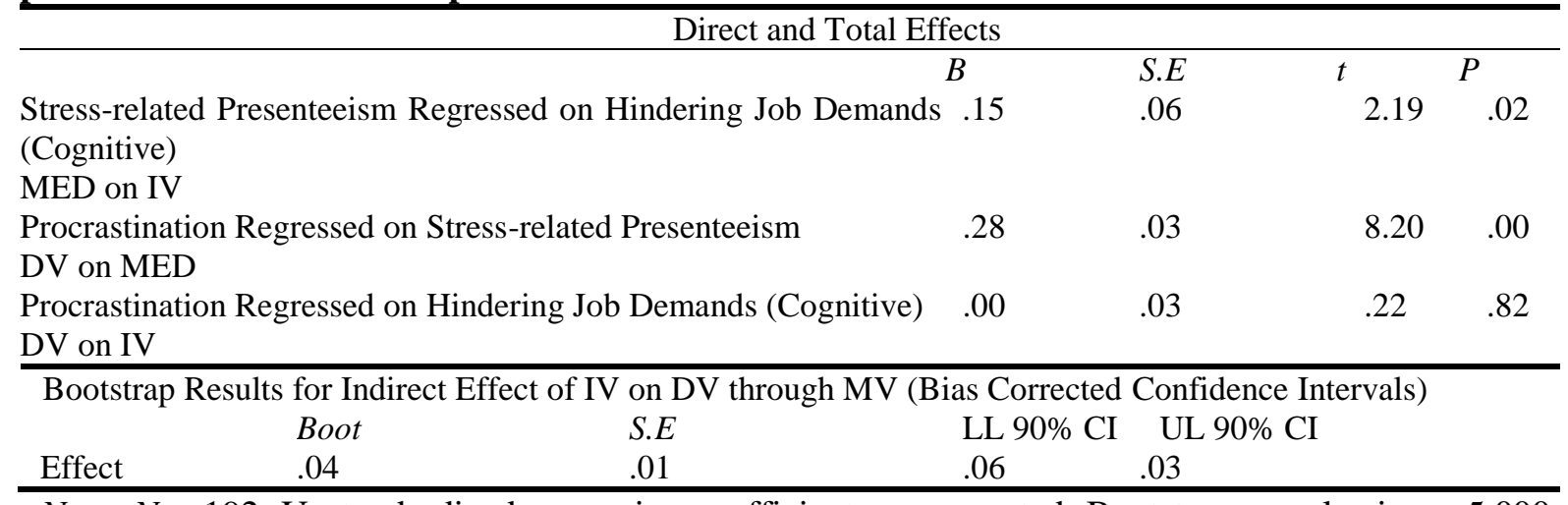

Note. $N=192$. Unstandardized regression coefficients are reported. Bootstrap sample size $=5,000$. 
$\mathrm{LL}=$ lower limit; $\mathrm{CI}=$ confidence interval; $\mathrm{UL}=$ upper limit. Age, gender and job nature were controlled in all analysis.

Moderating effects of psychological capital for the relationship between cognitive demands and stress-related presenteeism

To test Hypothesis 5, we used moderated regression analyses (Cohen, Cohen, West, \& Aiken, 2003). The controls were entered in the first step, followed by the independent variable and moderator in step 2 , and the interaction term in step 3. A significant interaction term is evidence of moderation. Table 3 (step 3) depicts that after controlling for the effects of age, job nature, experience, psychological capital and cognitive demands, the interaction term of cognitive demands and psychological capital had significant effect on stress-related presenteeism $\left(\beta=.21, \mathrm{p}<.05 ; \Delta \mathrm{R}^{2}=.27, \mathrm{p}<.05\right)$.

Table 3: Main Effects Regression and Moderation Results for Cognitive Job Demands, Psychological Capital and Stress-Related Presenteeism

\begin{tabular}{|c|c|c|}
\hline Variable & $\boldsymbol{\beta}$ & $\Delta \mathbf{R}^{2}$ \\
\hline \multirow{2}{*}{\multicolumn{3}{|c|}{$\begin{array}{l}\text { Step } 1 \\
\text { Control Variables }\end{array}$}} \\
\hline & & \\
\hline Age & -.00 & \\
\hline Job Nature & .10 & .02 \\
\hline Experience & .00 & \\
\hline \multicolumn{3}{|l|}{ Step 2} \\
\hline Cognitive Demands & $.38 * * *$ & \\
\hline Psychological Capital & $-.20 * * *$ & $.26 * * *$ \\
\hline \multicolumn{3}{|l|}{ Step 3} \\
\hline \multicolumn{3}{|l|}{$\begin{array}{l}\text { Cognitive Demands } \\
X\end{array}$} \\
\hline Psychological Capital & $.21 * *$ & $.27 * *$ \\
\hline
\end{tabular}

Dependent variable: Stress-Related Presenteeism

$\mathrm{N}=192, p<0.001 * * * p<0.05^{* *}$ Control variables - Age, Job Nature and Experience

Discussion

Presenteeism research has been quite theoretical (Johns, 2010) due to which studying presenteeism in the work setting becomes quite challenging. Therefore, the first challenge is to include several other theories to clarify the proposed theoretical structure. Secondly, identification of relevant literature becomes difficult because most of the studies have investigated presenteeism from a medical and health perspective (Cooper, 2016), where the majority of such studies define presenteeism as "coming to work while ill" (Johns, 2012) and investigate its subsequent relationship with the productivity loss. In this study stress-related presenteeism was defined as a situation in which "employees are physically present at their work, albeit their cognitive energy is diverted away from their work, preventing them from devoting full attention to their job (Gilbreath \& Karimi, 2012)."

The primary objective of this study was to examine the relationship of cognitive job demands with stress-related presenteeism using psychological capital as a moderator, and the subsequent relationship of presenteeism with procrastination, by using the job-demands resource model and conservation of resource theory.

The results supported a positive relationship between cognitive job demands and stressrelated presenteeism. Cognitive demands are a type of hindering demands, for whose fulfillment individuals have to expend more effort cognitively. Therefore, such demands can increase their stress levels. Moreover, hindering job demands are negatively appraised by individuals and are considered as threatening and creating obstacles for their personal growth (Lazarus \& Folkman, 1984). When individuals face uncertainty at work they become less cognitively engaged since they do not know what they have to do at work, and therefore will not be able to devote all their energies at work (Harter, Schmidt \& Hayes, 2002), and hence may become victims of stress-related presenteeism. Sanderson and colleagues conducted a study on the sensitivity of presenteeism measures and found that individuals reporting greater mental efforts were the ones who were more prone to fall victims of depression and presenteeism (Sanderson, Tilse, Nicholson, Oldenburg \& Graves, 2007).

The findings of this research offered evidence for the mediation of stress-related presenteeism between cognitive demands and procrastination. In a study conducted by Coutu et al., (2015), psychologically disturbing demands like cognitive demands were positively related to psychological 
stress which led to presenteeism. When individuals feel the pressure of cognitive demands, their energies are drained, which may result in distraction from the current task leading them to delay it.

The results also supported the moderating role of psychological capital. In a comprehensive review of literature provide by Newman et al., (2014), evidence has been provided of a whole stream of research that has studied the moderating effect of 'PsyCap' (at the individual level of analysis) between stressful demands and work-related outcomes, and reported the results similar to this study's results.

\section{Practical implications}

In efforts to reduce the negative effects of pressing job demands on employees, managers need to be trained so that they have an understanding about which type of job demands they should expend their energies, because employees have their coping mechanisms to deal with straining job demands. High cognitive demands may require high mental efforts on the part of the individual and this can be stressful. Positive psychological resources like psychological capital can be considered as relevant and meaningful for today's tempestuous work environment. The results of this study support that such resources can work as an effective coping mechanism and help individuals in dealing with hindering job demands.

\section{Conclusion}

This study reports the positive effect of cognitive job demands on stress-related presenteeism, where such presenteeism further induces procrastination. Moreover, the presence of psychological capital is found to weaken the effect of cognitive job demands on stress-related presenteeism. However, this study has some limitations (e.g., related to the usage of psychological capital as the only moderator, and adoption of quantitative research method). Future researchers may examine the effects of some context-related moderators (e.g., related to the type of industry/culture and demographic characteristics of the employees) for the relationships between job demands, presenteeism, and procrastination. Moreover, some in-depth qualitative investigation may be of good help to identify various antecedents and outcomes of stress-related presenteeism.

\section{References:}

Abbas, M., Raja, U., Darr, W., \& Bouckenooghe, D. (2014). Combined effects of perceived politics and psychological capital on job satisfaction, turnover intentions, and performance. Journal of Management, 40(7), 1813-1830.

Ackerman, D. S., \& Gross, B. L. (2005). My instructor made me do it: Task characteristics of procrastination. Journal of Marketing Education, 27(1), 5-13.

Akhtar, S., \& Malik, M. F. (2016). Effect of Boredom and Flexible Work Practices on the Relationship of WFC with Procrastination and Affective Commitment: Mediation of NonWork-Related Presenteeism. Global Journal of Flexible Systems Management, 17(4), 343356.

Bakker, A. B. (2011). An evidence-based model of work engagement. Current Directions in Psychological Science, 20(4), 265-269.

Bakker, A. B., \& Demerouti, E. (2007). The job demands-resources model: State of the art. Journal of Managerial Psychology, 22(3), 309-328.

Bakker, A. B., \& Demerouti, E. (2014). Job demands-resources theory. Wellbeing: A complete reference guide, 1-28.

Bakker, A. B., Schaufeli, W. B., Leiter, M. P., \& Taris, T. W. (2008). Work engagement: An emerging concept in occupational health psychology. Work \& Stress, 22(3), 187-200.

Bakker, A.B., \& Sans-Vergel, A.S. (2013). Weekly work engagement and flourishing: the role of hindrance and challenging job demands. Journal of Vocational Behavior, 83 (2013), 397-409.

Bakker, A.B., Hakanen, J.J., Demerouti, E., \& Xanthopoulou, D. (2007). Job resources boost work engagement, particularly when job demands are high. Journal of Education Psychology, 99, 274-284.

Bakker, A.B., Van Emmerick, H., \& Van Riet, P. (2008). How job demands, resources, and burnout predict objective performance? A constructive replication. Anxiety, Stress and Coping, 21, 309-324.

Barrick, M. R., Mount, M. K., \& Li, N. (2013). The theory of purposeful work behavior: The role of personality, higher-order goals, and job characteristics. Academy of Management Review, 38(1), 132-153. 
Blunt, A., \& Pychyl, T. A. (2005). Project systems of procrastinators: A personal project-analytic and action control perspective. Personality and Individual Differences, 38(8), 1771-1780.

Cascio, W. F. (1995). Whither industrial and organizational psychology in a changing world of work? American psychologist, 50(11), 928.

Cohen, P., Cohen, J., West, S., \& Aiken, L. (2003). Applied Multiple Regression/Correlation for the Behavioral Sciences, 3rd ed. Mahwah, New Jersey: L.

Cooper, C., \& Lu, L. (2016). Presenteeism as a global phenomenon: Unraveling the psychosocial mechanisms from the perspective of social cognitive theory. Cross-Cultural \& Strategic Management, 23(2), 216-231.

Coutu, M. F., Corbière, M., Durand, M. J., Nastasia, I., Labrecque, M. E., Berbiche, D., \& Albert, V. (2015). Factors associated with presenteeism and psychological distress using a theory-driven approach. Journal of occupational and environmental medicine, 57(6), 617-626.

Crawford, E. R., LePine, J. A., \& Rich, B. L. (2010). Linking job demands and resources to employee engagement and burnout: a theoretical extension and meta-analytic test. Journal of Applied Psychology, 95(5), 834-848.

D'Abate, C. P. (2005). Working hard or hardly working: A study of individuals engaging in personal business on the job. Human Relations, 58(8), 1009-1032.

Demerouti, E., \& Bakker, A. B. (2011). The job demands-resources model: Challenges for future research. SA Journal of Industrial Psychology, 37(2), 01-09.

Dormann, C., \& Zapf, D. (2004). Customer-related social stressors and burnout. Journal of occupational health psychology, 9(1), 61-82.

Fernet, C., Austin, S., Trépanier, S. G., \& Dussault, M. (2013). How do job characteristics contribute to burnout? Exploring the distinct mediating roles of perceived autonomy, competence, and relatedness. European Journal of Work and Organizational Psychology, 22(2), 123-137.

Gilbreath, B., \& Frew, E. J. (2008). The stress-related presenteeism scale [Measurement instrument]. Colorado State University-Pueblo, Hasan School of Business, Colorado State UniversityPueblo, Pueblo, CO.

Gilbreath, B., \& Karimi, L. (2012). Supervisor behavior and employee presenteeism. International Journal of Leadership Studies, 7(1), 114-131.

Harter, J. K., Schmidt, F. L., \& Hayes, T. L. (2002). Business-unit-level relationship between employee satisfaction, employee engagement, and business outcomes: A meta-analysis. Journal of Applied Psychology, 87, 268-279

Hobfoll, S. E. (2001). The influence of culture, community, and the nested- self in the stress process: Advancing conservation of resources theory. Applied psychology, 50(3), 337-421.Johns, G. (2010). Presenteeism in the workplace: A review and research agenda. Journal of Organizational Behavior, 31(4), 519-542.

Johns, G. (2011). Attendance dynamics at work: The antecedents and correlates of presenteeism, absenteeism, and productivity loss. Journal of Occupational Health Psychology, 16(4), 483500.

Johns, G. (2012). Presenteeism: A short history and a cautionary tale. Contemporary occupational health psychology: Global perspectives on research and practice, 2, 204-220.

Khattak, J.A., Khan, M.A., Haq, A., Arif, M. \& Minhas, A.A. (2011). Occupational stress and burnout in Pakistan's banking sector. African Journal of Business Management, 5(3), 810-817.

Lazarus, R. S., \& Folkman, S. (1984). Coping and adaptation. The handbook of behavioral medicine, 282-325.

LePine, J. A., Podsakoff, N. P., \& LePine, M. A. (2005). A meta-analytic test of the challenge stressor-hindrance stressor framework: An explanation for inconsistent relationships among stressors and performance. Academy of Management Journal, 48(5), 764-775.

Luthans, F., \& Youssef, C. M. (2004). Human, Social, and Now Positive Psychological Capital Management: Investing in People for Competitive Advantage. Organizational Dynamics, 33(2), 143-160.

Luthans, F., Youssef, C. M., \& Avolio, B. J. (2007). Psychological capital: Investing and developing positive organizational behavior. Positive organizational behavior, 9-24. 
Luthans, F., Avolio, B. J., Avey, J. B., \& Norman, S. M. (2007). Positive psychological capital: Measurement and relationship with performance and satisfaction. Personnel Psychology, 60(3), 541-572.

Malachowski, D. (2005). Wasted time at work costing companies billions. Retrieved from https://apexassisting.com/wasted-time-at-work-costing-companies-billions/www.salary.com

McGregor, A., Magee, C. A., Caputi, P., \& Iverson, D. (2016). A job demands-resources approach to presenteeism. Career Development International, 21(4), 402-418.

Metin, U. B., Taris, T. W., \& Peeters, M. C. (2016). Measuring procrastination at work and its associated workplace aspects. Personality and Individual Differences, 101, 254-263.

Miraglia, M., \& Johns, G. (2016). Going to work ill: A meta-analysis of the correlates of presenteeism and a dual-path model. Journal of Occupational Health Psychology, 21(3), 261-283.

Newman, A., Ucbasaran, D., Zhu, F., \& Hirst, G. (2014). Psychological capital: A review and synthesis. Journal of Organizational Behavior, 35(S1), S120-S138.

Petrou, P., Demerouti, E., Peeters, M. C., Schaufeli, W. B., \& Hetland, J. (2012). Crafting a job on a daily basis: Contextual correlates and the link to work engagement. Journal of Organizational Behavior, 33(8), 1120-1141.

Pychyl, T. A., \& Flett, G. L. (2012). Procrastination and self-regulatory failure: An introduction to the special issue, 203-2012.

Ruhle, S. A., Breitsohl, H., Aboagye, E., Baba, V., Biron, C., Correia Leal, C., ... \& Yang, T. (2020). "To work, or not to work, that is the question"-Recent trends and avenues for research on presenteeism. European Journal of Work and Organizational Psychology, 29(3), 344-363.

Sarwat, N., \& Abbas, M. (2020). Individual knowledge creation ability: dispositional antecedents and relationship to innovative performance. European Journal of Innovation Management. https://doi.org/10.1108/EJIM-05-2020-0198

Sarwat, N., \& Shahzad, K. (2017). An Investigation into the Role of Mindfulness on the Relationship between Hindering Job Demands and Stress-Related Presenteeism. Pakistan Journal of Social Sciences (PJSS), 37(2), 608-619.

Skowronski, M., \& Mirowska, A. (2013). A manager's guide to workplace procrastination. SAM Advanced Management Journal, 78(3), 4.

Sanderson, K., Tilse, E., Nicholson, J., Oldenburg, B., \& Graves, N. (2007). Which presenteeism measures are more sensitive to depression and anxiety?. Journal of Affective Disorders, 101(1), 65-74.

Schaufeli, W. B., \& Taris, T. W. (2005). The conceptualization and measurement of burnout: Common ground and worlds apart. Work \& Stress, 19(3), 256-262.

Schaufeli, W. B., \& Taris, T. W. (2014). A critical review of the job demands-resources model: Implications for improving work and health. In G. F. Bauer, \& O. Hammig (Eds.), Bridging Occupational, Organizational and Public Health: A Transdisciplinary Approach. (pp. 43-68). Dordrecht, Netherlands: Springer.

State Bank of Pakistan. (2020). Payment Systems Quarterly, July-September 2020. Accessed from: https://www.sbp.org.pk/psd/pdf/PS-Review-Q1FY21.pdf

Steel, P. (2007). The nature of procrastination: a meta-analytic and theoretical review of quintessential self-regulatory failure.

Tims, M., Bakker, A. B., \& Derks, D. (2013). The impact of job crafting on job demands, job resources, and well-being. Journal of Occupational Health Psychology, 18(2), 230-240.

Tuckman, B., \& Sexton, T. (1989). Effects of relative feedback in overcoming procrastination on academic tasks. Paper given at the meeting of the American Psychological Association, New Orleans, LA.

Tuckman, B. W. (1991). The development and concurrent validity of the procrastination scale. Educational and Psychological Measurement, 51(2), 473-480.

Van den Broeck, A., De Cuyper, N., De Witte, H., \& Vansteenkiste, M. (2010). Not all job demands are equal: Differentiating job hindrances and job challenges in the job demands-resources model. European Journal of Work and Organizational Psychology, 19(6), 735-759.

Van Veldhoven, M., \& Meijman, T.F. (1994). Questionnaire on the experience and evaluation of work (QEEW) Preliminary English version. Amsterdam National Research for Working Conditions, Brussels. 
Wan, H. C., Downey, L. A., \& Stough, C. (2014). Understanding non-work presenteeism: Relationships between emotional intelligence, boredom, procrastination and job stress. Personality and Individual Differences, 65, 86-90.

Xanthopoulou, D., Bakker, A. B., \& Fischbach, A. (2013). Work engagement among employees facing emotional demands: The role of personal resources. Journal of Personnel Psychology, 12(2), 74-84.

Xanthopoulou, D., Bakker, A. B., Demerouti, E., \& Schaufeli, W. B. (2007). The role of personal resources in the job demands-resources model. International Journal of Stress Management, 14(2), 121-141.

Xanthopoulou, D., Bakker, A. B., Demerouti, E., \& Schaufeli, W. B. (2009). Reciprocal relationships between job resources, personal resources, and work engagement. Journal of Vocational Behavior, 74(3), 235-244. 